\title{
STUDI KOMPARATIF KEPUASAN KONSUMEN SALON DAVINA SUMBERKIMA DENGAN SALON LELY SUMBERKIMA DI KECAMATAN GEROKGAK KABUPATEN BULELENG
}

\author{
Luh Rosi Ratna Ningsih¹, lyus Akhmad Haris², Kadek Rai Suwena ${ }^{3}$ \\ Program Studi Pendidikan Ekonomi \\ Universitas Pendidikan Ganesha \\ Singaraja, Indonesia \\ e-mail: rosiyahut1231@gmail.com¹, \\ iyusharis55@gmail.com² ${ }^{2}$ kadek suwena@yahoo.co.id ${ }^{3}$
}

\begin{abstract}
Abstrak
Penelitian ini bertujuan untuk mengetahui perbedaan kepuasan konsumen Salon Davina Sumberkima dengan Salon Lely Sumberkima di Kecamatan Gerokgak Kabupaten Buleleng. Jenis penelitian ini merupakan jenis penelitian kuantitatif dengan menggunakan metode komparatif. Populasi dalam penelitian ini adalah seluruh pengguna jasa di wilayah desa Sumberkima, Pemuteran, dan Pejarakan yang menggunakan jasa Salon Davina Sumberkima dan Salon Lely Sumberkima di Kecamatan Gerokgak Kabupaten Buleleng. Sampel yang digunakan dalam penelitian ini adalah sampel insidental. Data dikumpulkan dengan menggunakan metode kuesioner, dan dianalisis dengan menggunakan teknik analisis Independent Sample T-test. Hasil penelitian menunjukkan nilai t sebesar 6.481 dengan taraf signifikan 0,000 0,05 maka Ha diterima dan Ho ditolak. Jadi dapat disimpulkan bahwa terdapat perbedaan yang signifikan antara kepuasan konsumen Salon Davina Sumberkima dengan Salon Lely Sumberkima di Kecamatan Gerokgak Kabupaten Buleleng.
\end{abstract}

Kata kunci: Kepuasan Konsumen, Salon, Pemasaran, Jasa

\begin{abstract}
This study aims to determine the differences in consumer satisfaction at Salon Davina Sumberkima with Salon Lely Sumberkima in Gerokgak Sub-district Buleleng Regency. This type of research is a type of quantitative research using a comparative method. The population in this study were all service user in the village of Sumberkima, Pemuteran, and Pejarakan who use the services of Salon Davina Sumberkima and Salon Lely Sumberkima in Gerokgak Sub-district Buleleng Regency. The sample used in this study is incidental samples. Data were collected using a questionnaire and analysis of the Independent sample T-test. The results of the study showed a t value of 6.481 with a significant level of 0,000 $<0,05$ so Ha was accepted and Ho was rejected. So it can be concluded that there is a significant difference between costumer satisfaction at Salon Davina Sumberkima with Salon Lely Sumberkima in Gerokgak Sub-district Buleleng Regency.
\end{abstract}

Keywords : Customer Satisfaction, Salon, Marketing, Services

\section{PENDAHULUAN}

Dalam bisnis jasa kepuasan

konsumen merupakan tingkat perasaan

dimana seseorang menyatakan hasil perbandingan atas kinerja produk (jasa) yang diterima dan diharapkan. Memuaskan kebutuhan konsumen adalah keinginan setiap perusahaan. Selain faktor 
penting bagi kelangsungan hidup perusahaan, memuaskan kebutuhan konsumen dapat meningkatkan keunggulan dalam persaingan. Konsumen yang puas terhadap produk dan jasa pelayanan cenderung untuk membeli kembali produk dan menggunakan kembali jasa pada saat kebutuhan yang sama muncul kembali dikemudian hari. Hal ini berarti kepuasan merupakan faktor kunci bagi konsumen dalam melakukan pembelian ulang yang merupakan porsi terbesar dari volume penjualan perusahaan. Upaya menciptakan kepuasan konsumen bukanlah proses yang mudah, karena melibatkan pula komitmen dan dukungan aktif dari para karyawan dan pemilik perusahaan. Oleh sebab itu, sebenarnya proses penciptaan kepuasan konsumen merupakan sebuah siklus proses yang saling terkait antara kepuasan pemilik, kepuasan karyawan dan kepuasan konsumen.

Dalam menentukan kepuasan konsumen ada lima faktor yang harus diperhatikan oleh perusahaan yaitu kualitas produk, kualitas pelayanan atau jasa, emosi, harga dan biaya. Menurut Kotler dan Keller (2007a) mengatakan bahwa Kepuasan Konsumen adalah perasaan senang atau kecewa seseorang yang muncul setelah membandingkan kinerja (hasil) produk yang dipikirkan terhadap kinerja yang diharapkan. Kepuasan konsumen adalah sejauh mana manfaat sebuah prodak dirasakan (perceived) sesuai dengan apa yang diharapkan konsumen (Amir 2005). "Kepuasan konsumen adalah tingkat perasaan konsumen setelah membandingkan antara apa yang dia terima dan harapannya" (Husein Umar 2005). Memuaskan kebutuhan konsumen adalah keinginan setiap perusahaan. Seorang konsumen, jika merasa puas dengan nilai yang diberikan oleh produk atau jasa sangat besar kemungkinannya menjadi konsumen dalam waktu yang lama. Kepuasan Konsumen Menurut Swasta (2000) adalah "suatu dorongan keinginan individu yang diharapkan pada tujuan untuk memperoleh kepuasan". Kepuasan konsumen terhadap perusahaan jasa diartikan sebagai suatu keadaan dimana harapan konsumen terhadap pelayanan sesuai dengan kenyataan yang diterima tentang pelayanan yang diberikan kepada konsumen. Jika pelayanan suatu perusahaan dibawah harapan konsumen maka konsumen tentunya akan merasa kecewa. Begitu juga sebaliknya apabila pelayanan yang diberikan sesuai dengan keinginan konsumen maka tentunya konsumen akan merasa senang dan puas sehingga harapan konsumen dapat diketahui dari hasil yang didapatkan pada saat konsumen menggunakan pelayanan jasa yang ditawarkan oleh salon tersebut. Menurut Kotler dan Keller (2007a) mendefinisikan "jasa sebagai semua kegiatan atau manfaat yang dapat ditawarkan dari satu pihak kepada pihak lain yang pada dasarnya tidak berwujud dan tidak menghasilkan kepemilikan". Produksi jasa biasanya berhubungan dengan produk fisik maupun non fisik. Pengertidan jasa menurut Tjiptono (2011) mengataka bahwa "setiap tindakan atau perbuatan yang dapat ditawarkan oleh suatu pihak lain yang pada dasarnya bersifat tidak berwujud fisik (intangible) dan tidak menghasilkan kepemilikan suatu produksi jasa bisa berhubungan dengan produk fisik maupun non fisik".

Dari definisi diatas dapat disimpulkan bahwa produksi jasa dapat dikaitkan tidak hanya produk non fisik saja namun bisa juga berupa produk fisik dalam setiap produksinya.

Konsumen adalah seseorang yang secara kontinyu dan berulang kali datang ke suatu tempat yang sama untuk memuaskan keinginannya dengan memilih jenis pelayanan jasa dengan membayar jasa tersebut. Konsumen tidak hanya menginginkan pelayanan tertentu tetapi juga pelayanan dalam jumlah yang cukup dan mutu yang memadai. Untuk dapat memenuhi keinginan dan kepuasan konsumen perusahaan harus memberikan kualitas produk yang baik terhadap setiap konsumen yang datang. Sifat khusus jasa yang menyatakan diberikan oleh suatu pihak kepada pihak lain yang pada dasarnya tidak berwujud dan tidak mengakibatkan terjadinya perpindahan kepemilikan jasa. Untuk membantu 
perusahaan mempertahankan dan memperluas pangsa pasar. Kualitas tersebut harus diukur melalui sudut pandang konsumen terhadap produk itu sendiri, sehingga selera konsumen sangat berpengaruh dengan jenis perawatan yang ditawarkan dan yang terlibat dalam pemenuhan kebutuhan dan keinginan konsumen. Yang menyebabkan setiap perusahaan dan karyawan harus memprioritaskan kepuasan konsumen sebagai tujuan utama. Perusahaan dapat mengetahui kelemahan pelayanannya melalui beberapa sarana yaitu, survey konsumen secara berkala, kotak saran, dan sistim penanganan keluhan. Pekerjaan tersebut untuk meminimumkan jumlah keluhan dan juga untuk memaksimumkan kesempatan konsumen untuk menyampaikan keluhan agar perusahaan dapat mengetahui bagaimana pelayanan yang diberikan dan konsumen yang kecewa dapat memperoleh kepuasan.

Penampilan merupakan hal yang sangat penting terutama untuk kaum hawa. Setiap wanita tentu menginginkan penampilannya agar terlihat tetap menarik sehingga mereka perlu menggunakan pelayanan jasa salah satunya yaitu dengan memanfaatkan berbagai macam perawatan yang ada di salon kecantikan yang menawarkan berbagai jenis perawatan yang dapat membantu wanita agar penampilan mereka terlihat tetap menarik. Adanya kebutuhan dan permintaan konsumen dengan penampilan yang menarik dapat membuka peluang bisnis yang besar bagi para pengusaha atau pelayanan jasa untuk membuka tempat perawatan kecantikan atau sering disebut salon. Menurut Hakim (2001) salon adalah sarana pelayanan umum untuk kesehatan kulit, rambut dan tubuh dengan perawatan secara manual, preparatif, aparatif, dan dekoratif yang modern maupun tradisional tanpa adanya tindakan operasi (bedah). Salon kecantikan adalah sebuah tempat usaha yang bergerak di bidang jasa kecantikan yang berhubungan dengan perawatan kecantikan dan kosmetik untuk pria maupun wanita. Dimana salon kecantikan sebagai tempat untuk memperindah dan mempercantik tubuh dengan menyediakan perawatan berkaitan dengan kesehatan kulit, keindahan rambut, estetika wajah, perawatan kaki, perawatan kuku, waxing atau hair removal dan sebagainya yang berhubungan dengan pelayanan kecantikan. Di jaman sekarang salon adalah suatu usaha yang sudah banyak didirikan dan mudah untuk ditemukan di berbagai tempat baik di kota maupun di desa karena salon sudah menjadi kebutuhan pokok bagi masyarakat. Maka setiap salon tentunya menginginkan adanya kepuasan pada setiap konsumennya yang datang untuk melakukan perawatan, sehingga setiap salon atau perusahaan pasti memiliki strategi dan cara masing-masing agar konsumen tertarik untuk datang melakukan perawatan dan memenuhi kepuasan dengan cara memberikan pelayanan yang berkualitas. Fungsi utama dari salon sendiri pastinya sebagai wadah atau tempat utama untuk menyediakan jasa dan layanan yang berhubungan dengan mempercantik fisik dan sekaligus melakukan perawatan tubuh. Tipe salon kecantikan ada beraneka ragam, berikut tipe-tipe salon yang ada yaitu, Beauty Salon, Hair Salon, Salon \& Day Spa, Barber Shop, Nail Salon, Bridal Salon, dan Tanning Salon.

Keseimbangan di antara kepuasan konsumen, kepuasan pemilik dan kepuasan karyawan aspek tersebut merupakan tantangan sekaligus kunci keberhasilan pemasaran sebuah perusahaan. Bila karyawan puas dengan kondisi dan lingkungan kerjanya, mereka cenderung akan lebih berdedikasi atau berkomitmen besar dalam melayani setiap konsumen yang datang. Layanan bagus dilengkapi produk superior akan membuat konsumen puas. Mereka berpotensi tetap loyal pada produk dan perusahaan, sehingga tingkat defeksi konsumen (jumlah konsumen yang beralih ke pesaing) menjadi berkurang. Konsumen yang membeli ulang dan membeli produk lain dari perusahaan yang sama juga berpotensi memberikan pemasukan yang besar bagi perusahaan, sehingga pemilik akan puas. Pada gilirannya sebagian dari laba yang diperoleh dapat diinvestasikan 
kembali pada upaya peningkatan produktivitas dan kompetensi SDM perusahaan. Dengan demikian, siklusnya akan kembali pada kepuasan karyawan, konsumen dan pemilik.

Persaingan yang semakin ketat saat ini menjadikan konsumen semakin penting bagi kehidupan sebagian besar perusahaan. Sekarang ini konsumen dihadapkan pada pilihan berbagai jenis produk yang lebih banyak. Salon yang terdapat di Desa Sumberkima ada dua yaitu Salon Davina dan Salon Lely. Kedua salon tersebut tentu memiliki cara dan strategi yang berbeda dalam menawarkan jenis perawatan yang sebagian besar sama seperti, potong rambut, creambath, pelurusan rambut, mandi susu, rias wajah dan berbagai jenis perawatan lainnya. Pelayanan yang konsumen terima dari jasa yang ditawarkan oleh salon beragam dan berkualitas. Pelayanan yang berkualitas berperan penting dalam membentuk suatu kepuasan terhadap konsumen. Selain itu juga erat kaitannya dalam menciptakan keuntungan bagi perusahaan karena semakin berkualitas pelayanan yang diberikan oleh perusahaan maka kepuasan yang dirasakan oleh konsumen juga akan semakin tinggi.

Memuaskan kebutuhan konsumen adalah keinginan setiap perusahaan. Selain faktor penting bagi kelangsungan hidup suatu perusahaan, memuaskan kebutuhan konsumen juga dapat meningkatkan keunggulan dalam persaingan. Konsumen yang puas terhadap produk dan jasa pelayanan cenderung untuk membeli kembali produk dan menggunakan kembali jasa pada saat kebutuhan yang sama muncul kembali dikemudian hari. Hal ini berarti kepuasan merupakan faktor bagi konsumen dalam melakukan pembelian kembali yang merupakan porsi terbesar dari volume penjualan suatu perusahaan.

Salon Davina dan Salon Lely tentu memiliki kelemahan dan kelebihan tersendiri dimata konsumen. Menurut beberapa konsumen kualitas pelayanan yang terdapat di Salon Davina lebih menjanjikan dari kualitas pelayan yang terdapat di Salon Lely. Akan tetapi, tidak semua pelayanan yang diberikan di Salon Davina lebih berkualitas dibandingkan Salon Lely. Misalnya pelurusan rambut di Salon Davina lebih bagus daripada pelurusan yang ada di Salon Lely, akan tetapi pada saat melakukan potong rambut di Salon Lely hasil yang diberikan lebih maksimal dari hasil potong rambut diberikan di Salon Davina sehingga kualitas dan hasil potong rambut yang diberikan lebih minim dari salon Davina. Berdasarkan hal tersebut, dapat disimpulkan bahwa setiap salon memiliki kelebihan dan kekurangan tersendiri dimata konsumen yang patut untuk dipertahankan dan diperbaiki guna untuk tetap menjaga dan meningkatkan kepuasan konsumennya.

Untuk mempertahankan kedua eksistensi salon tersebut, maka perlu diadakan penelitian tentang tingkat kepuasan konsumen dari setiap salon yaitu Salon Davina dan Salon Lely. Fenomena persaingan yang ada pada Salon Davina dan Salon Lely mengarah ke sistem perekonomian dimana mekanisme pasar memposisikan pemasar untuk selalu mengembangkan dan merebut pangsa pasar (market share). Dalam dunia bisnis, pemasaran merupakan aktivitas menawarkan dan menjual produk. Menganalisa dan mengevaluasi tentang kebutuhan dan keinginan konsumen juga merupakan bagian dari pemasaran. Setiap perusahaan berusaha untuk selalu memenuhi kebutuhan dan keinginan konsumen melalui produk atau jasa yang dihasilkan dengan tujuan memperoleh keuntungan dari suatu proses pertukaran. Hal ini menuntut perusahaan agar dapat mengikuti perkembangan-perkembangan yang terjadi pada masyarakat saat ini seperti teknologi, pendidikan, dan gaya hidup masyarakat. Dengan mengikuti perkembangan yang ada diharapkan kegagalan dalam aktivitas pemasaran dapat diminimalisir.

Pemasaran adalah salah satu kegiatan pokok yang perlu dilakukan oleh perusahaan baik itu perusahaan barang maupun jasa dalam upaya untuk mempertahankan kelangsungan hidup usahanya. Karena pemasaran merupakan salah satu kegiatan perusahaan yang 
secara langsung berhubungan dengan konsumen. Maka kegiatan pemasaran dapat diartikan sebagai kegiatan manusia yang berlangsung dalam kaitannya dengan pasar. Kotler dan Keller (2007) mengemukakan definisi pasar berarti bekerja dengan pasar sasaran untuk mewujudkan pertukaran yang potensial dengan maksud memuaskan kebutuhan dan keinginan manusia, sehingga dapat dikatakan bahwa keberhasilan pemasaran merupakan kunci kesuksesan dari suatu perusahaan. Menurut Staton (2001) definisi pemasaran adalah suatu system keseluruhan dari kegiatan-kegiatan bisnis yang ditunjukkan untuk merencanakan, menentukan harga, mempromosikan dan mendistribusikan barang atau jasa yang memuaskan kebutuhan baik kepada pembeli yang ada maupun pembeli potensial. Pemasaran menurut Philiph Kotler (2008) adalah suatu proses sosial didalam individu dan kelompok untuk mendapatkan apa yang mereka butuhkan dan inginkan dengan menciptakan, menawarkan, dan secara bebas. Salah satu cara untuk mencapai keadaan tersebut adalah dengan meningkatkan kepuasan konsumen.

Oleh karena itu peneliti tertarik mengangkat topik tersebut dengan judul "Studi Komparatif Kepuasan Konsumen Salon Davina Sumberkima dengan Salon Lely Sumberkima di Kecamatan Gerokgak Kabupaten Buleleng".

\section{METODE}

Penelitian ini merupakan sebuah penelitian deskriptif komparatif. Populasi yang digunakan dalam penelitian ini adalah seluruh pengguna jasa di wilayah desa Sumberkima, Pemuteran, dan Pejarakan yang menggunakan jasa Salon Davina Sumberkima dan Salon Lely Sumberkima di Kecamatan Gerokgak Kabupaten Buleleng. Teknik pengambilan sampel yang digunakan adalah incidental atau kebetulan. Sumber data yang digunakan dalam penelitian ini adalah data primer. Data primer dalam penelitian ini adalah jawaban responden dari masyarakat desa Pemuteran,

Sumberkima, dan Pejarakan yang menggunakan jasa Salon Davina Sumberkima dengan Salon Lely Sumberkima di Kecamatan Gerokgak Kabupaten Buleleng.

Dalam melakukan penelitian, peneliti ini menggunakan metode kuesioner. Kuesioner digunakan untuk memperoleh data kepuasan konsumen Salon Davina Sumberkima dengan Salon Lely Sumberkima di Kecamatan Gerokgak Kabupaten Buleleng.

Instrumen penelitian ini berupa kuisioner, kuisioner untuk memperoleh data mengenai kepuasan konsumen Salon Davina Sumberkima dengan Salon Lely Sumberkima di Kecamatan Gerokgak Kabupaten Buleleng.

Dalam penelitian ini, metode analisis data yang digunakan yaitu $\mathrm{Uji} t$ karena penelitian ini merupakan penelitian analisis regresi linier sederhana. Adapun keputusan pengujian $t$-test Ho diterima atau ditolak, maka digunakan kriteria uji sebagai berikut.

Apabila $t_{\text {hitung }}>t_{\text {tabel }}(\alpha=0,05)$, maka Ho ditolak dan Ha diterima, berarti ada perbedaan yang signifikan Salon Davina Sumberkima dan Salon Lely Sumberkima pada masyarakat desa Pemuteran, Sumberkima, dan Pejarakan.

$$
\begin{aligned}
& \text { Apabila } t_{\text {hitung }}<t_{\text {tabel }} \quad(\alpha= \\
& 0,05),
\end{aligned}
$$

maka Ho diterima dan Ha ditolak, berarti tidak ada perbedaan yang signifikan Salon Davina Sumberkima dan Salon Lely Sumberkima pada masyarakat desa Pemuteran, Sumberkima, dan Pejarakan.

\section{HASIL DAN PEMBAHASAN Hasil Penelitian}

Berdasarkan data hasil penelitian yang telah dilakukan pada 30 responden mengenia kepuasan konsumen Salon Davina Sumberkima, maka diperoleh scoring secara total maupun perindikator. Hasil penelitian mengenai kepuasan konsumen Salon Davina Sumberkima di Kecamatan Gerokgak Kabupaten Buleleng dapat dilinat pada tabel 1. 
Tabel 1. Hasil perhitungan kepuasan konsumen Salon Davina Sumberkima Kecamatan Gerokgak Kabupaten Buleleng

No Indikator $\quad \begin{gathered}\text { Skor } \\ \text { Harapan }\end{gathered} \begin{gathered}\text { Skor } \\ \text { kualitas }\end{gathered} \begin{gathered}\text { Kepuasan } \\ \text { Konsumen }\end{gathered} \begin{gathered}\text { Kepuasan } \\ \text { Konsumen }\end{gathered}$ Kategori

(\%)

\begin{tabular}{|c|c|c|c|c|c|c|}
\hline 1 & $\begin{array}{llr}\begin{array}{l}\text { Kualitas } \\
\text { sesuai } \\
\text { sesuang diberikan } \\
\text { dijanjikan }\end{array} & \\
\end{array}$ & 223 & 214 & 0,96 & $96 \%$ & Sangat puas \\
\hline 2 & $\begin{array}{l}\text { Pelayanan yang baik dan } \\
\text { memberikan kepuasan } \\
\text { bagi konsumen }\end{array}$ & 226 & 209 & 0,92 & $92 \%$ & Sangat puas \\
\hline 3 & Kesessuaian harapan & 228 & 237 & 0,99 & $99 \%$ & Sangat puas \\
\hline 4 & Minat berkunjung kembali & 229 & 226 & 0,98 & $98 \%$ & Sangat puas \\
\hline \multirow[t]{2}{*}{5} & $\begin{array}{l}\text { Kesediaan } \\
\text { merekomendasikan }\end{array}$ & 234 & 232 & 0,99 & $99 \%$ & Sangat puas \\
\hline & Total & 1.140 & 1.118 & 0,98 & $98 \%$ & Sangat puas \\
\hline
\end{tabular}

Berdasarkan skor pada tabel. 1 yang berada pada rentang 0,81-1,00. kepuasan yang diberikan oleh Salon Indikator kesesuaian harapan memiliki Davina Sumberkima diperoleh dengan skor sebesar 0,99 yang berada pada cara membandingkan kualitas salon rentang 0,81-1,00. Indikator minat dengan harapan konsumen. Secara total berkunjung kembali memiliki skor sebesar dan perindikator kepuasan konsumen 0,98 yang berada pada rentang 0,81-1,00. Salon Davina Sumberkima berada pada Indikator kesediaan merekomendasikan kategori Sangat Puas. Kepuasan memiliki skor sebesar 0,99 yang berada konsumen secara total memiliki skor 0,89 yang berada pada rentang 0,81-1,00. Jika dilihat skornya perindikator maka pada indikator kualitas yang diberikan sesuai dengan yang dijanjikan memiliki skor sebesar 0,96 yang berada pada rentang $0,81-1,00$. Indikator pelayanan yang baik dan memberikan kepuasan bagi konsumen memiliki skor sebesar 0,92 pada rentang 0,81-1,00.

Berdasarkan data hasil penelitian yang dilakukan pada 30 responden mengenai kepuasan konsumen Salon Lely Sumberkima, maka diperoleh scoring secara total maupun peridikator. Hasil penelitian mengenai kepusan konsumen Salon Lely Sumberkima dapat dilihat pada tebel

Tabel 2. Hasil perhitungan kepuasan konsumen Salon Lely Sumberkima Kecamatan Gerokgak Kabupaten Buleleng

\begin{tabular}{|c|c|c|c|c|c|c|}
\hline No & Indikator & $\begin{array}{c}\text { Skor } \\
\text { Harapan }\end{array}$ & $\begin{array}{l}\text { Skor } \\
\text { kualitas }\end{array}$ & $\begin{array}{l}\text { Kepuasan } \\
\text { Konsumen }\end{array}$ & $\begin{array}{l}\text { Kepuasan } \\
\text { Konsumen } \\
(\%)\end{array}$ & Kategori \\
\hline 1 & $\begin{array}{llr}\begin{array}{l}\text { Kualitas } \\
\text { sesuai yang diberikan }\end{array} & \text { dengan yang } \\
\text { dijanjikan } & & \\
\end{array}$ & 203 & 118 & 0,58 & $58 \%$ & Kurang puas \\
\hline 2 & $\begin{array}{l}\text { Pelayanan yang baik dan } \\
\text { memberikan kepuasan } \\
\text { bagi konsumen }\end{array}$ & 227 & 204 & 0,89 & $89 \%$ & Sangat puas \\
\hline 3 & Kesessuaian harapan & 236 & 191 & 0,80 & $80 \%$ & Puas \\
\hline 4 & Minat berkunjung kembali & 206 & 145 & 0,70 & $70 \%$ & Puaas \\
\hline 5 & $\begin{array}{l}\text { Kesediaan } \\
\text { merekomendasikan }\end{array}$ & 232 & 172 & 0,74 & $74 \%$ & Puas \\
\hline & Total & 1.080 & 830 & 0,77 & $77 \%$ & Puas \\
\hline
\end{tabular}


Berdasarkan skor pada tabel. 2 kepuasan yang diberikan oleh Salon Lely Sumberkima diperoleh dengan cara membandingkan kualitas salon dengan harapan konsumen. Secara total dan perindikator kepuasan konsumen Salon Lely Sumberkima berada pada kategori Puas. Kepuasan konsumen secara total memiliki skor 0,77 yang berada pada rentang 0,61-0,80. Jika dilihat skornya perindikator maka pada indikator kualitas yang diberikan sesuai dengan yang dijanjikan memiliki skor sebesar 0,58 yang berada pada rentang 0,41-0,60. Indikator pelayanan yang baik dan memberikan kepuasan bagi konsumen memiliki skor sebesar 0,89 yang berada pada rentang 0,81-1,00. Indikator kesesuaian harapan memiliki skor sebesar 0,80 yang berada pada rentang 0,61-0,80. Indikator minat berkunjung kembali memiliki skor sebesar 0,70 yang berada pada rentang 0,61-0,80. Indikator kesediaan merekomendasikan memiliki skor sebesar 0,74 yang berada pada rentang 0,61-0,80.

Pada bagian hasil ini disajikan hasil penelitian untuk menguji signifikan perbedaan kepuasan Salon Davina Sumberkima dengan Salon Lely Sumberkima di Kecamatan Gerokgak Kabupaten Buleleng. Berdasarkan analisis Uji Independent Samepl T-Test dengan bantuan program SPSS 16.00 for windows. Adapun perbedaan dari kepuasan konsumen dapat dilihat pada tabel

Tabel 3. Hasil perhitungan group Statistics kepuasan konsumen Salon Davina Sumberkima dengan Salon Lely Sumberkima di kecamatan Gerokgak Kabupaten Buleleng

\section{Group Statistics}

\begin{tabular}{|c|c|c|c|c|c|c|}
\hline & NamaSalon & $\mathrm{N}$ & & Mean & Std. Deviation & Std. Error Mean \\
\hline \multirow[t]{2}{*}{ kepuasan konsumen } & salon lely & & 30 & 34.9667 & 6.26695 & 1.14418 \\
\hline & salon davina & & 30 & 39.1000 & 3.84484 & .70197 \\
\hline
\end{tabular}

Dapat dilihat dari tabel di atas bahwa rata-rata kepuasan konsumen Salon Davina Sumberkima dengan Salon Lely Sumberkima di Kecmatan Gerokgak Kabupaten Buleleng yaitu menunjukkan bahwa kepuasan konsumen Salon Davina
Sumberkima memiliki nilai sebesar 37.2667 dan Salon Lely Sumberkima memiliki nilai seebesar 30.0000 .

Hasil dari uji t independent sampel $T$ Test dapat dilihat pada tabel 4 .

Tabel 4. Hasil Uji Independent Sampel T-test Independent Samples Test

Levene's

Test for

Equality of

Variances

t-test for Equality of Means

\begin{tabular}{|c|c|c|c|c|c|c|c|c|c|c|}
\hline & & \multirow[b]{2}{*}{$\mathrm{F}$} & \multirow[b]{2}{*}{ Sig. } & \multirow[b]{2}{*}{$\mathrm{t}$} & \multirow[b]{2}{*}{ Df } & \multirow{2}{*}{$\begin{array}{c}\text { Sig. } \\
\text { (2- } \\
\text { tailed) }\end{array}$} & \multirow{2}{*}{$\begin{array}{c}\text { Mean } \\
\text { Difference }\end{array}$} & \multirow{2}{*}{$\begin{array}{l}\text { Std. Error } \\
\text { Difference }\end{array}$} & \multicolumn{2}{|c|}{$\begin{array}{c}\text { Interval of the } \\
\text { Difference }\end{array}$} \\
\hline \multirow[b]{2}{*}{ kepuasan konsumen } & & & & & & & & & Lower & Upper \\
\hline & Equal & & & & & & & & & \\
\hline & $\begin{array}{l}\text { variances } \\
\text { assumed }\end{array}$ & 155 & .695 & 6.481 & 58 & .000 & 7.26667 & 1.12130 & 5.02214 & 9.51120 \\
\hline & $\begin{array}{l}\text { Equal } \\
\text { variances } \\
\text { not } \\
\text { assumed }\end{array}$ & & & 57.815 & 48.122 & .000 & 7.26667 & 1.12130 & 5.02198 & 9.51135 \\
\hline
\end{tabular}


Berdasarkan hasil analisis uji Independent Sample T-Test dengan menggunakan bantuan SPSS 16.00 for windows, diperoleh nilai $t_{\text {hitung }}$ sebesar 6.481 sedangkan tabel sebesar 1.671 . Dengan demikian nilai thitung dibandingkan dengan tabel pada taraf signifikan 5\% ternyata nilai thitung lebih besar dari nilai

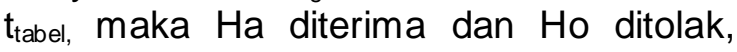
yang berarti terdapat perbedaan yang signifikan kepuasan konsumen Salon Davina Sumbekima dengan Salon Lely Sumberkima di Kecamatan Gerokgak Kabupaten Buleleng.

\section{PEMBAHASAN}

Berdasarkan hasil penelitian yang dilakukan bahwa kepuasan konsumen pada Salon Davina Sumberkima dan Salon Lely Sumberkima di Kecamatan Gerokgak Kabupaten Buleleng dapat diukur dengan menggunakan lima indikator yaitu kualitas yang diberikan sesuai dengan yang dijanjikan, pelayanan yang baik dan memberikan kepuasan bagi konsumen, kesesuaian harapan, minat berkunjung kembali, dan kesediaan merekomendasikan.

Adapun hasil penelitian yang dapat dilihat pada Salon Davina Sumberkima dari indikator yang pertama yaitu kualitas yang diberikan sesuai dengan yang dijanjikan menunjukkan bahwa Salon Davina Sumberkima berada pada kategori sangat puas, hal tersebut dikarenakan konsumen yang berkunjung ke Salon Davina Sumberkima mendapatkan hasil sesuai dengan keinginan dan harapan dari konsumen tersebut. Indikator yang kedua yaitu pelayanan yang baik dan memberikan kepuasan bagi konsumen menunjukkan bahwa Salon Davina Sumberkima berada pada kategori sangat puas, hal tersebut dikarenakan pelayanan yang diberikan oleh karyawan dan ketanggapan karyawan pada saat melayani konsumen sangat baik dan membuat konsumen nyaman untuk melakukan perawatan di Salon Davina Sumberkima. Indikator yang ketiga yaitu Kesesuaian harapan menunjukkan bahwa Salon Davina Sumberkima berada pada kategori sangat puas, hal tersebut dikarenakan apabila terdapat kesalahan atau ketidakpuasan atas hasil yang di dapatkan oleh konsumen Salon Davina Sumberkima akan memberikan service agar konsumen mendapatkan kepuasan yang diharapkan. Indikator yang keempat yaitu Minat berkunjung kembali menunjukkan bahwa Salon Davina Sumberkima berada pada kategori sangat puas, hal tersebut dikarenakan fasilitas yang disediakan oleh Salon Davina membuat konsumen merasa nyaman dan tidak jenuh pada saat menunggu dan ketersediaan peralatan yang digunakan juga sangat lengkap dan memadai sehingga konsumen berminat untuk melakukan kunjungan dan melakukan perawatan kembali ke Salon Davina Sumberkima. Indikator yang kelima yaitu Kesediaan merekomendasikan menunjukkan bahwa Salon Davina Sumberkima berada pada kategori Sangat Puas hal tersebut dikarenakan kepuasan yang dirasakan oleh konsumen yang berkunjung ke Salon Davina Sumberkima merasa sangat puas dan mendapatkan hasil yang sesuai dengan apa yang diharapkan, sehingga mereka bersedia untuk merekomendasikan Salon Davina Sumberkima.

Adapun hasil penelitian yang dapat dilihat pada Salon Lely Sumberkima dari indikator yang pertama yaitu kualitas yang diberikan sesuai dengan yang dijanjikan menunjukkan bahwa Salon Lely Sumberkima berada pada kategori kurang puas, hal tersebut dikarenakan konsumen yang berkunjung ke Salon Lely Sumberkima tidak mendapatkan hasil sesuai dengan keinginan dan harapan dari konsumen tersebut. Indikator yang kedua yaitu pelayanan yang baik dan memberikan kepuasan bagi konsumen menunjukkan bahwa Salon Lely Sumberkima berada pada kategori sangat puas, hal tersebut dikarenakan pelayanan yang diberikan oleh karyawan dan ketanggapan karyawan pada saat melayani konsumen sangat baik dan membuat konsumen nyaman untuk melakukan perawatan di Salon Lely Sumberkima. Indikator yang ketiga yaitu Kesesuaian harapan menunjukkan bahwa Salon Lely Sumberkima berada pada kategori puas, hal tersebut dikarenakan 
apabila terdapat kesalahan atau ketidakpuasan atas hasil yang di dapatkan oleh konsumen Salon Lely Sumberkima akan memberikan service agar konsumen mendapatkan kepuasan yang diharapkan. Indikator yang keempat yaitu Minat berkunjung kembali menunjukkan bahwa Salon Davina Sumberkima berada pada kategori puas, hal tersebut dikarenakan fasilitas yang disediakan oleh Salon Davina membuat konsumen merasa nyaman dan tidak jenuh pada saat menunggu dan ketersediaan peralatan yang digunakan juga cukup lengkap dan memadai sehingga konsumen berminat untuk melakukan kunjungan dan melakukan perawatan kembali ke Salon Lely Sumberkima. Indikator yang kelima yaitu Kesediaan merekomendasikan menunjukkan bahwa Salon Lely Sumberkima berada pada kategori Puas hal tersebut dikarenakan kepuasan yang dirasakan oleh konsumen yang berkunjung ke Salon Lely Sumberkima merasa puas dan mendapatkan hasil yang cukup sesuai dengan apa yang diharapkan, sehingga mereka bersedia untuk merekomendasikan Salon Lely Sumberkima.

Hasil penelitian dengan menggunakan Uji independent sampel T-test menunjukkan terdapat poerbedaan yang signifikan antara Kepuasan konsumen Salon Davina Sumberkima dengan Salon Lely Sumberkima. Kepuasan konsumen antara Salon Davina Sumberkima dengan Salon Lely Sumberkima di Kecamatan Gerokgak Kabupaten Buleleng menunjukkan bahwa kepuasan konsumen Salon Davina Sumberkima memiliki skor nilai rata-rata yang lebih tinggi dibandingkan dengan kepuasan konsumen Salon Lely Sumberkima. Perbedaan ini disebabkan karena seorang konsumen, jika merasa puas dengan nilai yang diberikan oleh produk atau jasa, sangat besar kemungkinannya menjadi konsumen dalam waktu yang lama atau konsumen tetap. Menurut P. Kotler (2009a) "kepuasan konsumen adalah perasaan senang atau kecewa seseorang yang timbul karena membandingkan kinerja yang dipersepsikan produk (hasil) terhadap ekspetasi (hasil) terhadap ekspetasi mereka.

\section{SIMPULAN DAN SARAN Simpulan}

Berdasarkan hasil penelitian yang dan pembahasan, maka dapat memberikan saran disimpulkan sebagai berikut.

Kepuasan konsumen Salon Davina Sumberkima berada pada kategori sangat puas.

Kepuasan konsumen Salon Lely Sumberkima berada pada kategori puas.

Hasil penelitian menunjukkan nilai $t$ sebesar 6.481 dengan taraf signifikan $0,000<0,05$ maka $\mathrm{Ha}$ diterima dan $\mathrm{Ho}$ ditolak. Jadi dapat disimpulkan bahwa terdapat perbedaan yang signifikan antara kepuasan konsumen Salon Davina Sumberkima dengan Salon Lely Sumberkima di Kecamatan Gerokgak Kabupaten Buleleng.

\section{Saran}

Berdasarkan hasil penelitian yang telah disimpulkan di atas, peneliti dapat memberikan saran sebagai berikut.

Dalam mempertahankan tingkat kepuasan konsumen hendaknya melakukan pelayanan yang baik dan mengutamakan kualitas produk yang digunakan.

Untuk menghindari berpindahnya konsumen ketempat lain hendaknya salon meningkatkan kualitas pelayanan dan produk yang digunakan, agar konsumen tertarik untuk tetap menggunakan jasa salon.

Untuk peneliti selanjutnya hendaknya lebih memperluas lagi penelitian mengenai tingkat kepuasan konsumen dan memperluas wilayah penelitian karena semakin luas wilayah penelitian maka akan didapatkan hasil yang lebih kongkrit dari suatu wilayah.

\section{DAFTAR PUSTAKA}

Amir, Taufiq. 2005. Dinamika Pemasaran Jelajahi Dan Rasakan. Jakarta: PT Raja Grafindo Persada.

Basu, Swastha. 2000. Manajemen Pemasaran Modern. Jakarta: PT. Raja Grafindo Persada. 
Hakim, Nelly. 2001. Kesmotologi Tata Kecantikan Kulit. Jakarta: Herni Kusanti, Pipin Tresna Prihatin, Wiwin Wiana.

Husein Umar. 2005. Metode Penelitian. Jakarta: Salemba Empat.

Kotler, Philip dan Gary Amstrong. 2008. Prinsip-Prinsip Pemasaran. Kedua belas. Jakarta: Erlangga.

Kotler, Philiph. 2009. Prinsip-Prinsip Pemasaran. Jakarta: Erlangga.

Philiph kotler dan Kevin Lane Keller. 2007. Manajemen Pemasaran. kedua. Jakarta: Erlangga.

Staton, William J. 2001. Prinsip Pemasaran. Jakarta: Erlangga.

Tjiptono, Fandy. 2011. Pemasaran Jasa. Malang: Banyumedia. 